\title{
МОВНІ ІНДИКАТОРИ ЯК ПІДГРУНТЯ КЛАСИФІКАЦІЇ АКТІВ ПОЗИТИВНОї І НЕГАТИВНОЇ РЕАКЦІї
}

Рябокінь Н. О. Мовні індикатори як підгрунтя класифікації актів позитивної і негативної реакції.

У статті розглянуто мовні індикатори функцій актів позитивної і негативної реакції, проаналізовано наявні класифікації індикаторів цих актів та запропоновано власну класифікацію.

Ключові слова: індикатор, позитивна / негативна реакція, мовленнєвий акт згоди / незгоди, стереотипні / нестереотипні індикатори, стандартний / нестандартний перформатив.

Рябоконь Н. А. Речевые индикаторы как основание классификации актов позитивной и негативной реакции.

В статье рассмотрены речевые индикаторы функций актов позитивной и негативной реакции, проанализированы имеющиеся классификации индикаторов этих речевых актов и предложена собственная классификация.

Ключевые слова: индикатор, позитивная / негативная реакция, речевой акт согласия / несогласия, стереотипные / нестереотипные индикаторы, стандартный / нестандартный перформатив. reaction.

Riabokin' N. O. Speech indicators as basis for classification of speech acts of positive and negative

The article deals with general characteristics of speech indicators of positive and negative reaction acts. Existing classifications of negopositive acts of speech are analyzed, and new classification is suggested.

Key words: indicator, positive / negative reaction, speech act of agreement / disagreement, stereotype / non-stereotype indicators, standard / non-standard performative.

Останнім часом увага вітчизняних та зарубіжних лінгвістів зосереджена на дослідженні мовних індикаторів функцій комунікативних актів. Привертають увагу дослідників й акти позитивної та негативної реакції, зокрема згоди та незгоди (В. І. Красних, Н. І. Поройкова, О.В.Озаровський, М.К.Любимова, Т. М. Свиридова та ін.). Метою нашого дослідження $є$ відбір, аналіз та класифікація вербальних індикаторів функцій актів позитивної та негативної реакції в українському мовленні. Відповідно до поставленої мети передбачено розв'язання таких завдань: з'ясувати суть поняття індикатор у лінгвістиці; розглянути різні 
підходи до вивчення мовленнєвих актів згоди та незгоди та класифікацій їх мовних засобів; відібрати та класифікувати мовні індикатори функцій негопозитивних актів.

Термін «індикатор», що походить від лат. indicare - «показувати» $[25$, с. 350$]$, часто вживається науковцями для позначення вербальних та невербальних засобів, які $\epsilon$ проявами певних лінгвальних явищ, насамперед функціональних. Ще Дж. Сьорль розрізняв два елементи синтаксичної структури речення: пропозиційний індикатор та індикатор ілокуції [20]. Останній указує, як слід розуміти пропозицію, а також яку ілокутивну роль повинно відігравати висловлювання $[6$, с. 120]. Б. М. Забавников та А. В. Уманець досліджували ілокутивні індикатори. Ілокутивні індикатори поділяються на лінгвістичні - граматичні, просодичні, лексичні, та екстралінгвістичні - ситуація чи контекст, порушення максим спілкування тощо [21, с. 198]. Б. М. Забавников до цих індикаторів зараховує порядок слів, наголос, розділові знаки, часові форми та способи дієслів, експліцитні перформативні формули [6, с. 120]. О.Г. Почепцов зазначає, що правила функціонування ілокутивного дієслова в ролі індикатора функцій визначаються наступними констатуючими ознаками ілокутивного акту: а) ілокутивний акт здійснюється мовцем; б) ілокутивний акт реалізується під час акту мовлення; в) ілокутивний акт певним чином впливає на адресата мовлення, оскільки має певну інтенцію та комунікативну спрямованість [17, с. 37].

Індикатор не $\epsilon$ виразником однозначного відношення між формою $\mathrm{i}$ змістом, тобто застосовується як «показник», а не як «ознака» [25, с. 353]. «Перлокутивні індикатори імпліцитного змісту - вербальні засоби, що вказують на наявність у висловленні перлокутивної мети адресанта донести до адресата ілокутивну і / або пропозиційну імплікацію» [3, с. 60]. Вербальні індикатори імпліцитних смислів становлять своєрідні «значеннєві віхи», «ключові слова», що дозволяють у процесі сприйняття висувати й коригувати гіпотези щодо змісту» [4, с. 95].

Цей термін також використовують науковці при дослідженні засобів вираження мовленнєвих актів. І. М. Осовська описує та класифікує мовленнєви індикатори відмови [12]. Т. М. Колокольцева розрізняє індикатори, які вказують на успішне та неуспішне декодування отриманої інформації. Індикатори позитивного результату - це комунікативи зрозуміло, ясно, а негативного - Тобто? У сенсі? [7, с. 107-108]. Н.Ф. Баландіна з'ясовує лексичні, граматичні i лексико-граматичні індикатори функціональних смислів та їх прагматичні характеристики в чеських прагматичних кліше ритуального, неритуального характеру: спонукання, оцінки, співпереживання, подяки, вибачення та негопозитивні (згоди, незгоди) тощо [2].

Також досить розповсюдженим у мовознавчій науці $є$ термін маркер [24, с. 118$]$. С. Г. Половініна у своїй роботі «Маркеры отрицания в 
немецкоязычном рекламном дискурсе» використовує ці три терміни як абсолютні синоніми [15]. М. К. Любимова приділяе увагу маркерам інтенційних смислів згоди та незгоди в російських та німецьких дискурсах засідань та переговорів [10].

У вище розглянутих працях використовуються терміни індикатор, маркер та мовний засіб як синонімічні. Ми будемо використовувати, керуючись працями Дж. Сьорля, Н. Ф. Баландіної, Т. М. Колокольцевої та інших, термін індикатор акту позитивної / негативної реакції. Під індикаторами інтенційних смислів розуміємо «елемент висловлювання, породжуваного в мовленнєвому акті, що експлікує ілокутивну силу» [23, с. 144], зокрема негопозитивні (термін негопозитивний уведений нами як узагальнена назва актів позитивної і негативної реакції). Майже кожен iз дослідників мовних засобів негопозитивної реакції намагався класифікувати цю групу. В. І. Красних розглядає типові мовленнєві формули згоди / незгоди й класифікує їх з огляду на стилі мови [9], не беручи до уваги численні конструктивні різновиди згоди чи незгоди.

О. В. Озаровський розмежував засоби вираження згоди та незгоди на три групи. До першої групи належить лексико-граматичний повтор висловлювання співрозмовника в межах, достатніх, 3 одного боку, для показу правильності осмислення його повідомлення, 3 іншого - задля пізнавання адресантом своїх думок [11, с. 113]. До другої - форми семантично спеціалізованих і синтаксично нечленованих слів-речень типу: так / нi, звичайно. Слова-речення передають лише комунікативномодальні значення згоди чи незгоди, які можуть бути виражені однією лексемою [Там само, с. 115]. Третю складають лексично вільні i синтаксично членовані речення, які не є повтором чужого висловлювання (не можу не погодитися, ви маєте рацію).

H. І. Поройкова виокремлює два структурно-семантичні типи: 1) конструкції 3 повтором, які можуть бути експліцитними й імпліцитними; 2) конструкції з словами схвальної / несхвальної семантики [16]. До другого типу позитивної та негативної реакції належить коло лексики, яке утворює лексико-семантичну групу схвалення / підтвердження - несхвалення / непідтвердження. Сюди входять: 1) слова, які використовуються під час опозиції мовець / слухач; 2) слова i висловлювання, які оцінюють висловлювання $з$ огляду на відповідність дійсності. Отже, дослідниця виокремлює синтаксичні та лексичні способи.

За М. К. Любимовою, згода та незгода поділяється на повну та неповну. Серед висловлювань позитивної та негативної реакції, як повної, так і неповної, дослідниця виділяє спеціалізовані та неспеціалізовані $[10$, с. 47]. До спеціалізованих мовних засобів повної / неповної згоди / незгоди належать: 1) стверджувальний / заперечний релятив $\partial а$ / нет й ін.; 2) модальні слова (конечно, безусловно); модальні сполуки: можна сказать; 3) коротка форма прикметника согласен / не согласен; форма 
дієслова договориться (не договориться); 4) маркери позитивної / негативної конотації: прекрасно, ужастно; 5) частка тоже й сурядний сполучник $i$ тощо [Там само, с. 167].

Неспеціалізовані мовні засоби повної / неповної згоди / незгоди представлені так: частковий повтор репліки-стимула, синтаксичні та займенникові заміни, сурядні сполучники [Там само, с. 168].

Слід зазначити, що класифікація М. К. Любимової досить розгалужена й багатоаспектна. Свою класифікацію авторка базувала на тому, як мовні засоби здатні виражати інтенційні смисли. У своєму дослідженні М. К. Любимова підмічає досить тонкі нюанси, зокрема стверджуючи, що сурядний сполучник $i$ в певних контекстах може виражати згоду [Там само, с. 81]: Bы будете наказаны за такое качество! - И наказывайте, хоть на всю зарплату [Там само, с. 107]. Ми схильні такі випадки відносити до повторів, але звісно $i$ в їхньому складі виконує функцію прагматичного посилення: - Ану, як ти бігаєщ? - I побіжу (П. Панч), надаючи згоді значення виклику. Повний повтор ініціальної репліки у функції згоди розглядає, але чомусь не виокремлює його ні у спеціалізованих, ні в неспеціалізованих засобах вираження негопозитивної реакції. А цей індикатор $\epsilon$ досить поширеним реалізатором згоди та незгоди як в усному, так і в писемному мовленні. Він привертав увагу багатьох учених, зокрема Н. І. Поройкової, О. В. Озаровського, Т. М. Свиридової та інших.

Т. М. Свиридова у своій роботі паралельно використовує терміни мовний засіб і маркер як синонімічні. Виявляє та характеризує специфіку базових лексичних засобів вираження мовленнєвого акту згоди та незгоди та їх семантичні параметри, розглядає актуальні фразеологічні одиниці у функції згоди / незгоди. Мовні засоби цих актів поділяє на основні та неосновні (ядерні / периферійні). Основні включають лексичні та фразеологічні засоби [19]. Серед спеціалізованих мовних засобів вираження негопозитивної реакції авторка називає іменники (згода / незгода), дієслова (погоджуватися / не погоджуватися) та прикметники як якісні поширювачі (мовчазна згода / незгода). Пропонуючи типологію конструкцій з семантикою згоди / незгоди, описує структурно-синтаксичні типи конструкцій, які реалізують ці мовленнєві акти [Там само, с. 8]. Семантичним ядром висловлювань згоди / незгоди $\epsilon$ значення спеціалізованих (базових) засобів, до яких належать лексичні та фразеологічні одиниці у функції позитивної або негативної реакції. Граматичний центр поля належить дієсловам та коротким прикметникам. А периферійні мовленнєві особливості характеризуються «складними переплетеннями основного позитивного / негативного значення з іншими семантичними категоріями, які зменшують повноту реалізації згоди / незгоди» [Там само, с. 13]. 
Розглянуті вище класифікації мовних засобів висловлювань згоди та незгоди мають різне підгрунтя - лексико-граматичне, семантичне, синтаксичне та прагматичне. Проаналізований матеріал засвідчує те, що мовленнєве явище згоди та незгоди і його індикація привертає увагу лінгвістів. Але низка проблем ще чекають свого розв'язання, зокрема проблема класифікації аналізованих мовленнєвих актів на основі їх мовної індикації.

У процесі спілкування значна кількість логічно і граматично правильних реплік, що об'єктивно відображає дійсність, може викликати позитивну чи негативну реакцію. Нас цікавлять як стереотипні, так і нестереотипні конструкції позитивної та негативної реакції. Використовуючи цю термінологію, керуємося працями М. К. Любимової, яка, як уже було зазначено вище, поділяє мовні засоби згоди / незгоди на спеціалізовані / неспеціалізовані [10]; дослідженнями Т. М. Свиридової про основні (ядерні) та неосновні (периферійні) формули вираження негопозитивів (за авторкою, основні засоби і є спеціалізованими [19]); розвідками Н. Ф. Баландіної, яка використовує у своїй монографії терміни стереотипний / нестереотипний індикатор функиії [2]. Отже, стереотипні - це основні, загальноприйняті, шаблонні формули вираження мовленнєвих актів згоди чи незгоди у спілкуванні, а нестереотипні - це неосновні (периферійні), незагальноприйняті, нешаблонні індикатори негопозитивної реакції.

До стереотипних індикаторів функцій позитивної та негативної реакції відносимо перформативні конструкції, а до нестереотипних повтори ініціальної репліки та цитатні запитання. Перформативні формули поділяються на стандартні (класичні) та нестандартні («некласичні» [8, с. 187]). Стандартні репрезентовані перформативними дієсловами в першій особі однини або множини теперішнього часу дійсного способу: - Ви не проти? - Я згоджуюсь (В. Винниченко); - Професія шахтаря важка, незавидна... - Не погоджуюсь (В. Гжицький ).

Нестандартні - це синонімічні граматичні еквіваленти, які реалізують значення перформативності й можуть бути виражені не лише дієсловом, а будь якою частиною мови: іменником (-Там їх ніхто не поиупить. - Згода, сусіде! (Ю. Логвін); прикметником (-Мій майстер краси! Художник! - Незгодний (В. Минко); часткою (- Це не інстинкт. Навпаки... - Нехай (Ю. Мушкетик). Адже гра 3 формою не змінює основного змісту висловлювання, якщо можна виявити перформативну глибинну структуру [14]. На ці синонімічні формули звертала увагу О. А. Россолова у праці «Перформатив як координатор комунікативної взаємодії і засіб адресованості», називаючи їх, услід за Дж. Остіном та ін. $[13$, с. $62-63]$, експліцитними $[18$, с. 8]. Ю. Д. Апресян, услід за О.В. Падучевою, говорив про пріоритет перформативних формул над перформативними дієсловами [1, с. 203]. 
Нестандартні негопозитивні перформативи формують польову структуру, ядро якої становить індикатор так / нi, який має інваріантне значення згоди / незгоди i повністю відповідає стандартним перформативам, тобто Так = Погоджуюся, $\mathrm{Hi}=$ Не погоджуюся. У центр поля доцільно включити другу групу - модально-семантичні відповідники перформативів (цей термін також використовує О. А. Россолова $[18$, с. 9]), репрезентовані такими індикаторами: модальні дієслова можу / не можу та под. у першій особі однини чи множини в теперішньому часі дійсному способі + дієслова погодитися / не погодитися та под., у неозначеній формі: - Сьогодні гарний день. - Хочу (можу) погодитися (не погодитися) з тобою (3 усного мовлення). До центру можна віднести й третю групу - оцінні висловлювання, представлені індикаторами добре, дурниці та под. у функції згоди або незгоди: - Нехай коней розпряжуть, $a$ збрую зараз однеси в комору, щоб якої реміняки не порізали на батоги. Добре (І. Карпенко-Карий); - Але правда, ти хвилювався б так само, якби це була не я, а якась інша. - Дурниці (Ю. Мушкетик). У периферію поля входить четвертий тип - конструкції з дієсловами мовленнєвої і розумової діяльності (розуміти, думати): - Невже чимось схожий? - Думаю... (Ю. Мушкетик); - Може, ви помилились щчодо об'єкта вияву ваших почуттів? - Не думаю (М. Самсонова), п'ята група - істиннісні висловлювання, репрезентовані конструкціями 3 лексемами правда, неправда та под., у функції згоди та незгоди, наприклад: - Та бiда знайде, хоч $i$ в піч замажся. - Правда (І. Карпенко-Карий); - А любов може вичахти. - Неправда, - заперечив він (Ю. Мушкетик). Сюди ж входить шоста група - фразеологізми у функції згоди / незгоди: - То Яну. - Маєш рацію (А. Багдай); - Ти вперто маєш мене за божевільного! - Бійтесь бога! (В. Винниченко), сьома, що представлена неспеціалізованими етикетними кліше, на зразок Дякую, Спасибі, як ввічлива згода / незгода: - Сiдайте, бо картопля зачахне. - Спасибі (М. Стельмах); - Я хочу довірити тобі серйозну справу. - Дякую Гришо! (М. Самсонова) і восьма конструкції зі словами хай / нехай, все одно та под. як байдужа згода: - Чорногуз, - підправив третій. - Все одно, - уперто сказав перший (Ю. Мушкетик).

До нестереотипних негопозитивних індикаторів належить повтор ініціальної репліки, який може бути: а) повним: - I я. - I я (О. Олесь); б) неповним: - Їдьмо на гору! - Їдьмо! - вигукнув Тарас (М. Шаповал); в) $з$ додатковою інформацією: - Ви нашу бачили сестру? Вона сліпа... Бачили і чули ї̈ прекрасний голо (О. Олесь). У повторах іноді відбувається певна модифікація граматичних форм, порівняно з ініціальною реплікою, зокрема займенникові заміни: - $\boldsymbol{T} \boldsymbol{u}$ чесний перед собою? - Перед собою-то я чесний... (К. Світличний).

Нестереотипними $\epsilon$, на наш погляд, і цитатні запитання, які представлені: а) власне запитаннями: - У мене такий день, такий день!... - 
Хіба тільки в тебе? (М. Самсонова); б) хто-, щзо-, чому-питаннями: - Жид злупе такого проценту, щзо ніяк не викрутишся потім. - Хто ж тепер, куме, не лупить? (І. Карпенко-Карий); - Ну, Саню? - Що жн? Можу (В. Винниченко).

Отже, у нашому дослідженні з'ясовано суть поняття індикатор ілокутивної функції в зарубіжній та вітчизняній лінгвістиці, розглянуто різні підходи до вивчення мовленнєвих актів згоди / незгоди та їх класифікацій, що стало підгрунтям створення власної класифікації індикаторів функцій актів згоди / незгоди.

\section{Література}

1. Апресян Ю. Д. Перформативы в грамматике и словаре / Ю. Д. Апресян // Избранные труды : в 2-х т. - М. : Школа «Языки русской культуры», 1995. - Т.2. - С. 199-218.

2. Баландіна Н. Ф. Функції і значення чеських прагматичних кліше в комунікативному контексті : [монографія] / Н. Ф. Баландіна. - К. : АСМІ, 2002. - 332 с.

3. Безугла Л. Р. Перлокутивні індикатори імпліцитного смислу у висловлнннях німецької мови / Л. Р. Безугла // Вісник ХНУ № 848. - 2009. - С. 58-62.

4. Горелов И. Н. Невербальне компоненты коммуникации / И. Н. Горелов. - М. : КомКнига, 2006. $112 \mathrm{c}$.

5. Дейк ван Т. А. Язык. Познание. Коммункация / Т. А. ван Дейк. - М. : Прогресс, 1989. - 312 с.

6. Забавников Б. Н. К проблеме структурирования речевого акта (речевого действия) / Б. Н. Забавников // Вопросы языкознания. - 1984. - № 6. - С. 119-124.

7. Колокольцева Т. Н. Спецефические коммуникативные единицы диалоической речи / Т. Н. Колокольцева. - Волгоград : Изд-во Волгоградского госуниверситета, 2001. - 260 с.

8. Косик И. А. К проблеме классификации перформативов / И. А. Косик // Сб. научн. докладов ХІ международной конференции по функциональной лингвистике. - Ялта, 2004. - С. 186-188.

9. Красных В. И. Выражение согласия-несогласия с высказванием собеседника / В. И. Красных // Русский язык за рубежом. - 1970. - № 1. - С. 28-31.

10. Любимова М. К. Интенциональные смыслы согласия и несогласия в русских и немецких дискурсах совещаний и переговоров : дис... канд. филол. наук : 10.02.19 / М. К. Любимова. - Тамбов, 2004. - $196 \mathrm{c}$.

11. Озаровский О. В. Соглисие-несогласие как категория коммуникативного синтаксиса (в грамматике русского языка для иностранцев) / О. В. Озаровский // Проблемы учебника русского языка как иностранного. Синтаксис : сб. науч. трудов. - М., 1980. - С. 109-120.

12. Осовська I. М. Висловлювання-відмова : структурно-семантичний та комунікативнопрагматичний аспекти (на матеріалі сучасної німецької мови) : автореф. дис... канд. філол. наук : 10.02 .04 / І. М. Осовська. - К., 2003. - 20 с.

13. Остин Дж. Слово как действие / Дж. Остин // Новое в зарубежной лингвистике. - М. : Прогресс, 1986. - Вып № 17 : Теория речевых актов. - С. 22-130.

14. Падучева Е. В. Высказывание и его соотношение с действительностью / Е. В. Падучева. - М. : Наука, 1985. - 271 с.

15. Половинина С. Г. Маркеры отрицания в немецкоязычном рекламном дискурсе / С .Г. Половинина // Гуманитарные исследования. - 2010. - № 4 (36). - С. 112-118.

16. Поройкова Н. И. Функционирование средств выражения согласия-несогласия в диалоге / Н. И. Поройкова // Функциональный анализ грамматических категорий и единиц : сб. науч. трудов. - Л., 1976. - С. 102-115.

17. Почепцов О. Г. Основы прагматического описания предложения / О. Г. Почепцов. - К. : Вища шк. : Изд-во при КГУ, 1986. - С. 24-59.

18. Россолова О. А. Перформатив как координатор коммуникативного взаимодействия и средство адресованности : автореф. дис... к-та филол. наук : 10.02.01 / О. А. Россолова. - М., 2008. - 24 с.

19. Свиридова Т. М. Категория согласия / несогласия в русском языке : автореф. дис... док. филол. наук : 10.02.01. / Т. М. Свиридова. - Елец, 2008. - 20 с.

20. Серль Дж. Что такое речевой акт / Дж. Серль // Новое в зарубежной лингвистике. - 1986. - № 17. - C. $151-170$.

21. Уманець А. В. Лінгвістичні та екстралінгвістичні ілокутивні індикатори непрямих мовленнєвих актів / А. В. Уманець // Наук. праці Камянець-Подільського ун-ту. - Вип. 3. - Т. 2., Камянець-Подільськ, 2004. - C. 197-200. 
23. Штерн І. Б. Вибрані топіки та лексикон сучасної лінгвістики. Енциклопедичний словник для фахівців з теор. гуман. дисциплін та гуман. інформатики / І. Б. Штерн. - К., «АртЕк», 1998. - 336 с.

24. Recanati F. Meaning and force : The pragmatics of performative utterances / F. Recanati; translation of Les enonces performatifs, published : Paris : Editions minuit, 1981. - Cambridge : Cambridge Univ. Press, 1987. - 278 p.

25. Sager S. F. Sprache und Beziehung. Linguistische Untersuchungen zum Zusammenhang von sprachlicher Kommunikation und zwischenmenschlicher Beziehung / S. F. Sager. - Tibingen : Niemeyer, 1981. - 488 s. 